\title{
Use of risk-management as a new technology in the system of education management
}

\author{
I. S. Paslavska \\ Luhansk Taras Shevchenko National University, Starobilsk, Ukraine \\ Corresponding author. E-mail: Ira_Markova@ukr.net \\ Paper received 23.07.19; Accepted for publication 09.08.19.
}

\section{https://doi.org/10.31174/SEND-PP2019-201VII81-06}

\begin{abstract}
Actuality of material, stated in the article, is conditioned by the necessity of maintenance and increase of competitiveness of higher educational establishments at the market of educational services. Implementation of risk management in activity of higher educational establishments is rather new direction in the system of higher educational institutions government in Ukraine, that will give an opportunity to correct strategy of development taking into account the degree of risk, to promote effectiveness of functioning of educational institutions and provide development in the conditions of uncertainty, overcoming negative and following positive tendencies.
\end{abstract}

Keywords: risk-management, higher educational institution, quality, efficiency, government system, educational services.

On the modern stage of development of education and science on the whole higher educational establishments run into the row of problems and requirements, overcoming and decision of that guarantee maintenance of competitiveness at the market of educational services. In order to higher educational establishment function properly and occupy rating positions, successfully overcoming any problems and confusions, it is necessary reorganization of the system of management. It may be complete abandonment from traditional system of management or only partial use of such new technologies in the system of education management as riskmanagement.

Without regard to necessity and actuality of introduction of technologies of risk management for the system of management of higher educational establishment, research vocabulary of risk management in education is worked out not enough. But on the whole practice of use of technologies of risk management in the system of education management in our country is enough new direction.

The aim of this research consists in realization of analysis of scientific and research, methodological literature of last decades and generalization the state of research of the use of technologies of risk management in higher educational establishments.

During last decades more often risk becomes the object of interest of scientists in the sphere of management activity. Such scientists as I.Arliukova, V.Hrynova, V.Kravchenko, V.Koiuda, O.Koiuda, A.Starostina, O.Ponomarenko, S.Romaniuk, V.Cherkasov and others dedicated their works to this question.

The following scientists S.Bilousova, M.Bieliaieva, T.Kostiukova, I.Lysenko, N.Nikitina, V.Chuprov, P.Shchehlov and others dedicated their works to the study of risks in education.

Without regard to practical and theoretical value on this stage of development of pedagogical science the problem of risk and risk management is considered not enough, more in detail this problem is examined in economy, banking, philosophy, psychology.

The approaches and methods of use of aspects of risk management are not generalized until now in higher educational establishment management in national science and practice.

In the result of conducted analysis of the titles (231 titles) of dissertations, articles, textbooks, study letters, monographs and collections of scientific works the following is educed: $45 \%$ of analized literature is dedicated to consideration of risk and risk management as an economic category and only in $30 \%$ risk and risk-management is studied in the sphere of education and pedagogy, other $25 \%$ of literature dedicated to consideration of these concepts in such spheres as management, psychology, philosophy, law, innovative activity, management, sport, navigation and pharmacology.

This analysis confirms novelty and insufficient investigation of such categories as "risk" and "risk-management" in pedagogy and education.

Risk-management was formed in separate science in the second half of XX century. Risk management becomes a science in 1973. Risk management becomes a new paradigm of strategic management in modern business in the middle of 90s of XX century. Fast growth of internet, globalization, development of market of derivative instruments, informative and technological development cardinally changed approaches to management of risks.

Risk-management is a continuous, all-embracing system of risk management of organization that includes the complex of different methods and means that are refered to removal of obstacles at the achievement of main business purposes of a company.

Risk-management or management of risks is a comparatively new direction in the theory and practice of management that confidently took the place among the modern methods of management.

In Ukraine risk-management on enterprises practically fully is taken to insurance. There are separate works in investment and banking sphere; annually (from 2000) the questions of financial risks management are discussed within the framework of the East Europe forum in risk management [1].

There are already such standards in some countries of Europe and world. Thus such normative acts are absent in our country. The leading developers of standards in risk management are Canadian and Japanese associations of standards, Organization in standards of Australia, International organization in standardization (IOS) and International electrical engineering commission (IEEC), Austrian institute of standards and so on.

Risk-management is refered to identification of risks, their analysis and estimation, and also to development of measures refered to struggle with risks with the aim of receipt of most benefit for optimal for establishment or enterprise risk level.

Risk-management must be a permanent process that analyses development of establishment or enterprise in the pro- 
cess of activity, that is past, present and future of establishment or enterprise on the whole. It must be integrated to general culture of organization, accepted and approved by organizational leadership, and then carried to each employee of organization as a general program of development of establishment concrete tasks on places. Risk-management as a single system of risk management must contain the control program of implementation of the set tasks, estimation of efficiency of measures that are conducted, and also system of encouragement on all levels of organization.

There is a large variety of classifications of risks in literature depending on aims. Classification of risks means systematization of plenty of risks on the basis of certain signs and criteria that allow to unite the subsets of risks in certain groups.

The conducted content-analysis of classifications of risks testifies to absence of the single approach to classification, as there are more than 40 different criteria of risks and more than 220 kinds of risks.

Existing nowadays classifications of risks allow to divide them into a few groups on different features:

by the scale of origin: macrorisks (they form due to factors that take place in the scale of the certain state); mesorisks (they form due to factors, that take place in the scale of certain industry, for example, the industry of education); microrisks (they form due to factors that take place in the scale of educational establishment);

by source: external (unconnected directly with activity of educational establishment) and internal (result of activity);

by time: short-term (risks related to operative daily activity of educational establishment), medium-term (situational risks appearance of that can be a little bit remote from the moment of exposure and acceptance of corresponding decision) and long-term (risks that are considerably remote in time from the moment of acceptance and realization of management decision and have prolonged action within the limits of the system);

by the term of action: retrospective risks (related to the decisions that were accepted in educational establishment in the past, but realized now), current (correlated with current activity of educational establishment, change under the act of constantly operating risk factors), perspective (related to the possible changes of conditions of risk subject operating conditions presently, that in the future can change a risk situation in educational establishment);

by the nature of display: political (instability of the political system, activity of government bodies, that is predefined by ethnic, regional problems, by polarization of interests of social groups and others like that) and economic risks (unfavorable changes in economic activity of country, region, educational establishment, different levels of management and so on);

by the sphere of origin: political and legal, financial and economic, organizational and technical, personnel, administrative, informative and communication, sociocultural, learning and teaching.

It should be noted that identical external risks can differently influence even on alike organizations. Character and depth of influence of external risks depend on the location of organization, presence of its necessary resources, degree of use of existent potential, creativity of management, organizational culture and others like that [2, p.225].
On the basis of analysis of scientific literature, personal experience of work at higher educational establishment, personal observations and expert questioning the following risks of higher educational establishment were distinguished.

Approximate list of risks of higher educational establishment

- Difficult demographic situation

- Reduction of budgetary financing of higher educational establishment

- Recall of license for delivery of learning services

- Falling of consumer interest

- Increase of competition

- High inflation

- Falling of profits of population

- Absence of demand for specialists

- Educational services of subzero quality

- Instability of home policy situation in the state

- Risk of changes of legislation in relation to adjusting (regulation) of activity of educational establishments

- Imperfection of mechanisms of bringing in money of partners (grants, sponsor payments and others like that)

- Insufficiency of inventory and logistics management of educational establishment

- Disparity to technical, sanitary, fire and other norms of safety of vital functions

- Reduction of professionally-qualifying level of personnel at educational establishment

- Stuff turnover at educational establishment

-Demotivation of personnel of educational establishments.

On the basis of the distinguished risks it is possible to offer next classification:

- sociopolitical risks (difficult demographic situation; instability of home policy situation in the state, reduction of the amount of prospective students, impossibility of employment of graduating students, reduction of student body)

- state-legal risks ( recall of license for delivery of learning services; risk of changes of legislation in relation to adjusting (regulation) of activity of educational establishments)

- financial and economic risks (reduction of budgetary financing of higher educational establishments; high inflation; falling of profits of population; imperfection of mechanisms of bringing in of money of partners (grants, sponsor payments and others like that), reduction or loss of financial resources, insufficient budgetary financing, imperfection of mechanisms of bringing in of money of partners (grants, sponsor payments and others like that)

- risks related to activity of higher educational establishments as a subject of market relations (falling of consumer interest, increase of competition, absence of demand for specialists, educational services of subzero quality, insufficient level of preparation of students, insufficient level of competence of graduating students, inefficiency of the system of education, absence of prestige of the national system of education due to its inefficiency or corrupted, absence of prestige of higher educational establishment due to its insufficient level of preparation of students or corrupted, subzero indexes in rating, unattractiveness of higher educational establishment for foreign students)

- risks related to insufficiency of material and technical base (insufficiency of inventory and logistics management of educational establishment, disparity to technical, sanitary, fire and other norms of safety of vital functions, insufficient quantitative indexes of material and technical base, insufficient quality indexes of material and technical base) 
- risks related to educational research staff of higher educational establishment (reduction of professional and qualifying level of personnel in educational establishment, staff turnover in educational establishment, demotivation of personnel of educational establishments, insufficient quality (qualification) of teaching staff, reduction of professional and qualifying level of personnel, reduction of amount of teachers, display of professional destructions among teaching staff, decline of efficient factor of teachers as a result of decline of motivation, insufficient quality of management).

In the process of the activity higher educational establishments run into the row of threats and risks that are necessary being warn before their coming-in or overcome in the case of coming-in. An ideal variant for non-admission of coming-in of risk situations can be warning management, that includes realization of necessity not only in identification and processing of risks but also in identification of possibilities and threats.

International standards in risk management give an opportunity to use any methods, means and technologies of estimation, processing and management of risks. As a rule this is used for quality and quantitative estimation of risks. International standards also envisage realization of parametrization of risks, id est determination of risk parameters: probability, degree of importance of risk, its co-operating with other risks, validity of measures of risk processing. Also, according to international standards there is a sorting approach in practice of risk management, id est experts examine a few possible variants of administrative decisions, and elect the variant of decision, the acceptance of that diminishes probability of risk situation coming-in.

The key moment of risk management is in our opinion not so much exposure of risks as foresights of threats (circumstances or events that arise up in the external and internal environment of higher educational establishment, that can become a reason of efficiency reduction of higher educational establishment activity and making realization of the put aims impossible), that can negatively influence on higher educational establishment activity.

Risk - management is refered to reduction and neutralization of risks, continuous control of risk situation.

The process of risk management consists of certain stages, however their amount and sequence is not a permanent in- dex, because there is a certain variety of scientists' opinions on this question.

As a result of the conducted analysis of approaches of scientists to the selection of the stages of risk management, it is possible to come to the conclusion, that almost all authors distinguish such stages, as identification, analysis, choice of methods of reacting, control.

Having analyzed existent stages of risk management we can distinguish own stages:

1. Exposure of risk

2. Identification (attributing of risk to the certain group)

3. Analysis or parametrization of risks (evaluation of probability, degree of importance, co-operating with other risks, prioritization)

4. Choice of methods of risk management

5. Design of risk situations and possible variants of overcoming of these situations

6. Expert estimation of variants of administrative decisions

7. Acceptance of administrative decisions that diminish probability or make impossible risk situation coming-in

8. Realization of administrative decisions

9. Monitoring and analysis of efficiency of administrative decisions

So far, educational establishments are competent subjects of market economy. There is increase of requirements of population to quality of education, professional competence of graduating students, updating of technologies of studies, intensifying of competitive activity at the market of educational services. For maintenance of competitiveness and development of educational establishments in quickly changeable operating conditions it is necessary not only to monitor the condition of market of educational services and to assess own situation at this market but also to apply the methods of prognostication of market development, develop alternative variants of activity depending on changes of external environment.

Higher educational establishments need to develop and introduce the system of monitoring and identification of risks at the market of educational services, as risks that are formed in external environment directly influence on functioning of educational establishment.

\section{ЛИТЕРАТУРА}

1. Східноєвропейський форум з ризик-менеджменту. Режим доступу: [http://www.fas.com.ua/event.php?id=82]

2. Ткачук С.В. Специфіка формування продуктової політики підприємств сфери послуг / С.В.Ткачук, С. А.Стахурська, В.О.Стахурський // Актуальні проблеми економіки. - 2015. - N 4.- C. $220-228$.

3. Заюков I. Проблеми та перспективи розвитку в Україні професійного навчання кадрів на виробництві/І.Заюков, Н.Коваль/Економіка України. - 2008. - № 6. - С. 80-87.

4. Дудко П.М. Науково-практичні основи формування конкурентних переваг в системі стратегічного управління вищим

\section{навчальн}

№ 5. - С. 225-232.

5. Гальчинський А.С. Основи економічної теорії [підручник] /А.С.Гальчинський, П.С.Сщенко, Ю.І.Палкін. - К.: Вища освіта, 1995. - 471c.

6. Старостіна А. О. Ризик-менеджмент: Теорія та практика: навч. посіб./ А. О. Старостіна, В. А. Кравченко. - К.: Політехніка, 2004. - $200 \mathrm{c}$.

7. Хриков Є. М. Управління навчальним закладом: навч. посіб. / Є. М. Хриков. - К.: Знання, 2006. -365 с.

\section{REFERENCES}

1. The East Europe forum in risk management. Retrieved from;: [http://www.fas.com.ua/event.php?id=82]

2. Tkachuk S.V. Specific of forming of food politics of enterprises in service industry. - Actual problems of economics. 2015.- N 4.- p.220-228.

3. Zaiukov I. Problems and prospects of development of personnel professional training in industries in Ukraine.. - 2008. - № 6. - p. 80-87.

4. Dudko P.M. Research and practice bases of forming of competitive advantages in the system of strategic management of higher educational establishment. - 2013. - № 5. - p. 225-232.

5. Halchynskyi A.Ye. Bases of economic theory- Kyiv: High education, $1995-471 \mathrm{p}$.

6. Starostina A.O. Risk-management: theory and practice. Kyiv: Politechnik, 2004. - 200 p.

7. Khrykov Ye.M. Management of educational establishment.Kyiv: Knowledge, 2006. - 365 p. 